\title{
Twenty years of ATP-binding cassette (ABC) transporters
}

\author{
Bruno Stieger • Christopher F. Higgins
}

Published online: 8 November 2006

(C) Springer-Verlag 2006

ATP-binding cassette $(\mathrm{ABC})$ transporters constitute a large superfamily of primary active transport systems, which play a diversity of physiological roles, and are found in all cells of all kingdoms [3]. The year 2006 marks the 20th anniversary of the identification of this superfamily of proteins in 1986 [4]. It is also the 30th anniversary of the molecular identification of P-glycoprotein (MDR1, ABCB1) [5], which, when its gene was sequenced in 1986, turned out to be the first mammalian example of the $\mathrm{ABC}$ transporter family. It seems appropriate to celebrate these milestones in $\mathrm{ABC}$ transporter research with a special issue. It is the aim of this issue to give an overview on current knowledge and novel findings on mammalian $\mathrm{ABC}$ proteins, highlighting the many achievements of 30 years of research in the field. It complements a special issue on $\mathrm{ABC}$ transporters in FEBS Letters, which appeared earlier this year [2].

In mammals, seven families of $\mathrm{ABC}$ transporter genes have been defined, coding for 48 individual transporters. Although the number of mammalian $\mathrm{ABC}$ proteins is much smaller than found in prokaryotes many are of major clinical significance; currently, 18 human $\mathrm{ABC}$ genes have been associated with genetic diseases [1].

All ABC transporters consist of four core domains [4]: two transmembane domains, each normally consisting of, most frequently, six transmembrane alpha-helices (TMD1 and TMD2), and two nucleotide binding domains (NBD1 and NBD2). These four core domains form the minimal functional unit. However, there are many variations on this

\footnotetext{
B. Stieger $(\bowtie)$

Institute of Clinical Pharmacology and Toxicology,

Department of Medicine, University Hospital,

8091 Zurich, Switzerland

e-mail: bstieger@kpt.unizh.ch

C. F. Higgins

MRC Clinical Sciences Centre, Faculty of Medicine,

Imperial College, Hammersmith Hospital Campus,

Du Cane Road, London W12 0NN, UK
}

theme. For example, the four domains of mammalian $\mathrm{ABC}$ transporters may be fused together in a number of ways, either as a single polypeptide or as two half transporters each consisting of one TMD and one NBD. The MRP (ABCC1, $\mathrm{ABCC} 2, \mathrm{ABCC} 3, \mathrm{ABCC} 6, \mathrm{ABCC} 8, \mathrm{ABCC} 9$, and $\mathrm{ABCC} 10)$ proteins have an additional transmembrane domain (TMD0) of unknown function. In addition, although the vast majority of $\mathrm{ABC}$ proteins are active transporters, there are exceptions where evolution has adapted the ATPswitch mechanism, which appears to have evolved to drive transport to other activities. Thus, one mammalian $\mathrm{ABC}$ protein is an ion channel (CFTR; ABCC7) and another is a regulator of ion channel activity (SUR; $\mathrm{ABCC} 8$ and ABCC9). Other $\mathrm{ABC}$ proteins couple ATP binding and hydrolysis to the control of translation or DNA repair. Those that are not transporters are not covered in this special issue.

We would like to thank the $\mathrm{ABC}$ community for devoting their time and energy to writing these chapters; we would also like to thank those who contributed to the field many stimulating thoughts, ideas, and good scientific times, though not specifically in writing. Finally, we thank Heini Murer from Pflüger's Archives for his continuous support in making this special issue possible.

\section{References}

1. Dean M, Annilo T (2005) Evolution of the ATP-binding cassette (ABC) transporter superfamily in vertebrates. Annu Rev Genomics Hum Genet 6:123-142

2. Flugge U, van Meer G (2006) ABC Transporters. FEBS Lett 580(4):

3. Higgins $\mathrm{CF}$ (1992) ABC transporters: from microorganisms to man. Annu Rev Cell Biol 8:67-113

4. Higgins CF, Hiles ID, Salmond GP, Gill DR, Downie JA, Evans IJ, Holland IB, Gray L, Buckel SD, Bell AW et al (1986) A family of related ATP-binding subunits coupled to many distinct biological processes in bacteria. Nature 323: 448-450

5. Juliano RL, Ling V (1976) A surface glycoprotein modulating drug permeability in Chinese hamster ovary cell mutants. Biochim Biophys Acta 455:152-162 